https://doi.org/10.5719/aub-g/69.1/1

\title{
GEOHISTORY OF CARTOGRAPHY OF GEOMORPHOLOGICAL RISKS IN ROMANIA - GENERAL APROACH
}

FLORINA GRECU' ${ }^{1}$, MĂDĂLINA TEODOR ${ }^{1}$, CARMEN CAMELIA RĂDULESCU $^{1}$

Abstract

The main objective of risk research is their identification, mapping and pre-study. The article presents the evolution of the notions defining the extreme phenomena, in close dependence with the development of the geosciences studying them. Terrain cartography and implicitly geomorphological risk phenomena were and are of particular importance for society, taking into account both anthropogenic interventions in the geomorphological landscape and especially their negative effects. In addition, geomorphological hazards are highly dependent on spatial expansion, which leads to the need for their cartographic representations.

Development of risk mapping in Romania highlights concepts:

- mapping processes, landforms, as well as the development of dynamic geomorphology as a science;

- the study of extreme phenomena, their consequences, the mapping of vulnerability, the use of computerized techniques, the legend and the scale, the means used (maps with large and medium scale).

Keywords: risks, hazards, legend, scale, cartography, Romania.

\section{Introduction and objectives}

The paper presents the evolution of the notions that define the extreme events, in close dependence in the development of the geosciences that study them. The chronological and historical classification is achieved

1 University of Bucharest, Faculty of Geography, Department of Geomorfologie,

Pedologie, Geomatics florinagrecu@yahoo.com, mada.teodor@yahoo.com; carmencameliaradulescu@yahoo.com 
by referring both to the bibliography and to the social and applied character of the knowledge in the field. Thus, both geographical and geohistorical and paleo geographic principles of scientific research are pursued. The mapping of the relief and implicitly of the phenomena of geomorphological risk events have had and still have a special importance for the society, considering both the anthropic interventions in the geomorphological landscape and, particularly, their negative effects. In addition, the geomorphological risks have a close dependence on their spatial extension, thus their cartographic representation becoming a real necessity. Hazard and vulnerability maps are a way of spatial evaluation of the hazard from the risk maps.

The cartography, the methodology for elaboration of the geomorphological map, the main instrument of two-dimensional rendering of the three-dimensional forms, imposes to the researcher a good professional training in the fields of general and dynamic geomorphology, topography, legends and scales representations. In addition, the researcher must have the capacity for spatial evaluation of the phenomena (Dramis and Bisci 1998). This capacity is amplified, in the case of the assessment of the vulnerabilities and geomorphological risks, by the ability to reproduce in time the dynamics of these processes.

Geographic mapping and cartography clearly includes the mapping of the topographic surface of the relief, under different aspects (shape, anthropogenic impact, the shape response to this impact etc.). These experienced a gradual evolution, being dependent on the evolution of the sciences, but also on the evolution of geography as a science, distinguishing a beginning stage, an older one, and a second stage, modern. In this context, we mention for the older period, the maps from the $\mathrm{XVI}^{\text {th }}$ century (Chorographia Transylvaniae, 1532, by Johannes Honterius and Dacia, 1541, that render all three Romanian countries) and XVIII th century: Map of the Romanian Country, 1700, Padova, Constantin Cantacuzino, Map of Moldova accompanying the work Descriptio Moldaviae by Dimitrie Cantemir, printed in Hague in 1737 (Victor Sficlea and Ioan Popovici in the Geography of Romania, 1983, vol I). Dimitrie Cantemir's map shows more clearly for the first time, the mountain massifs (Baican 1996). The basis of the later topographic maps is the Austrian military maps, on a large scale, of 
which it is worth mentioning Hora von Otzellowitz's map, 1790, made in hatches, which allows detailed analysis on the relief. Drawing masterpieces during the First World War - 1916 - and the topographic map from 1951-1958 (and later editions) render details of the topographic surface in large and very large scales (Osaci-Costache 2008), being used for diachronic analysis.

\section{Risk maps and their importance}

Thematic risk maps show the territorial distribution, the dynamics and the evolution of the natural processes established according to the genetic classifications, detailing degree being required by the scale according to the objectives of the study (Figure 1) (Grecu 2002a, 2013, 2016, 2018a, 2018b).

In this matter, we can distinguish:

- partial risk maps (of the risk generated by different processes and phenomena such as: torrentiality, landslides, avalanches, floods, seismic phenomena, sea waves etc.);

- general risk maps (the exposure to the risk of all lands from a limited area, regardless of the process or phenomenon that generates it).

The analysis of the extreme natural phenomena in various stages of development (hazard, vulnerability, risk, disaster) is a part of normal evolution of the natural respectively geomorphological processes (Grecu 1997). In this regard, there is a risk in nature, related to the processes that take place in the environment, or both a physical and human risk (Grecu 1997, 2009, 2016; Paniza 1990; Birkmann 2006, cited in Grecu 2016).

Among the first geomorphological risk maps made in Romania were those oriented towards the natural processes that generate the environmental risk, except the flood maps that targeted the effects on the society and the anthropic environment. Within them, special attention was paid to hazard and vulnerability maps, either as the main objective of the analysis or as obligatory steps in the elaboration of the risk maps.

The general map of the geomorphological risk is carried out in successive stages of research. Being a synthetic one, this map is based on 
analytical maps. The detail methodology can be modified, depending on the geographical and geological particularities. These stages are (Grecu 1997):

- analysis of morphodynamic potential and elaboration of analytical maps;

- analysis of geomorphological processes/hazards and map elaboration;

- land vulnerability analysis and map elaboration;

- the regionalization of morphodynamic factors and processes, according to quantitative parameters and mapping in the field;

- the study of risk elements;

- elaboration of the geomorphological risk synthesis map.

Consequently, studies on geomorphological phenomena of risk concern the dynamics of processes, respectively their mapping and regionalization.

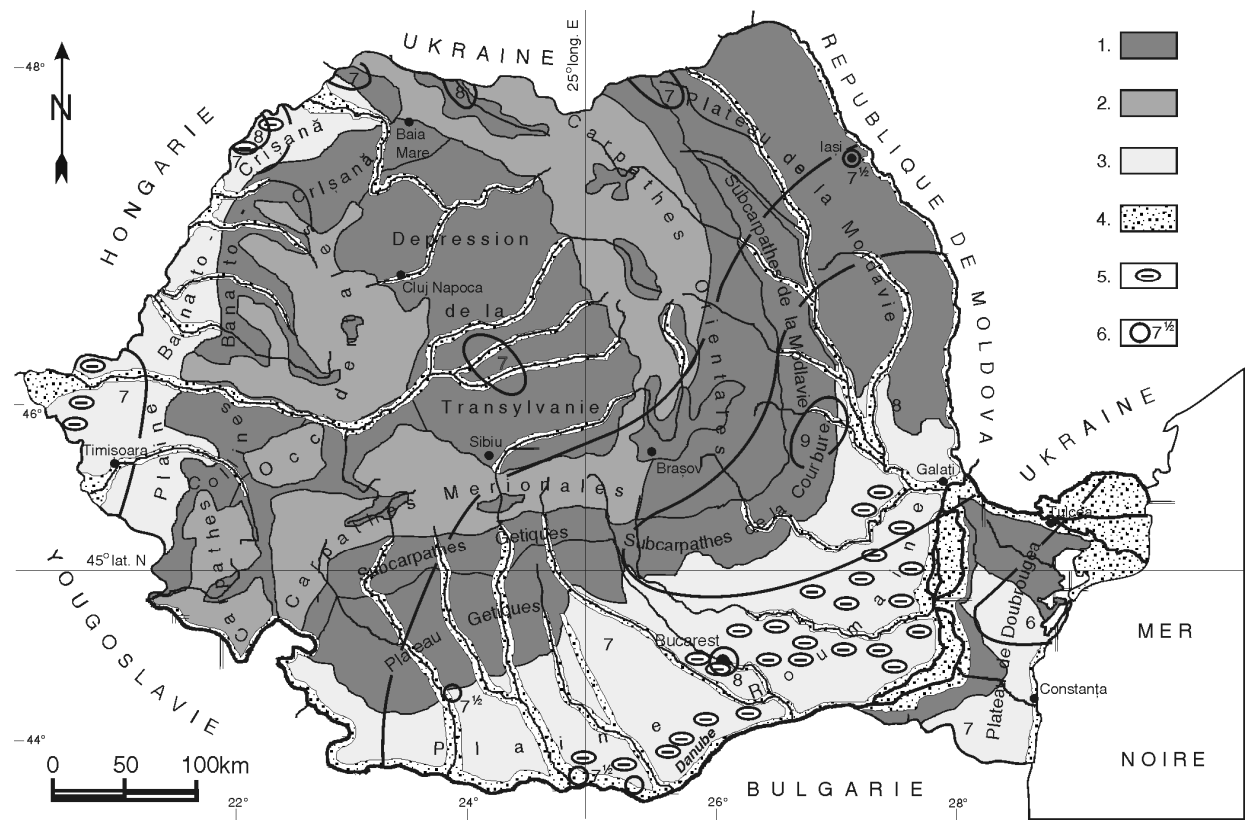

Fig. 1. A the map of the geomorphological risk on a small scale a Romanian territory: 1. high risk; 2 . medium risk; 3 . low risk; high or very high risk areas at: 4. floods; 5 . piping and down-sagging; 6 . earthquakes 


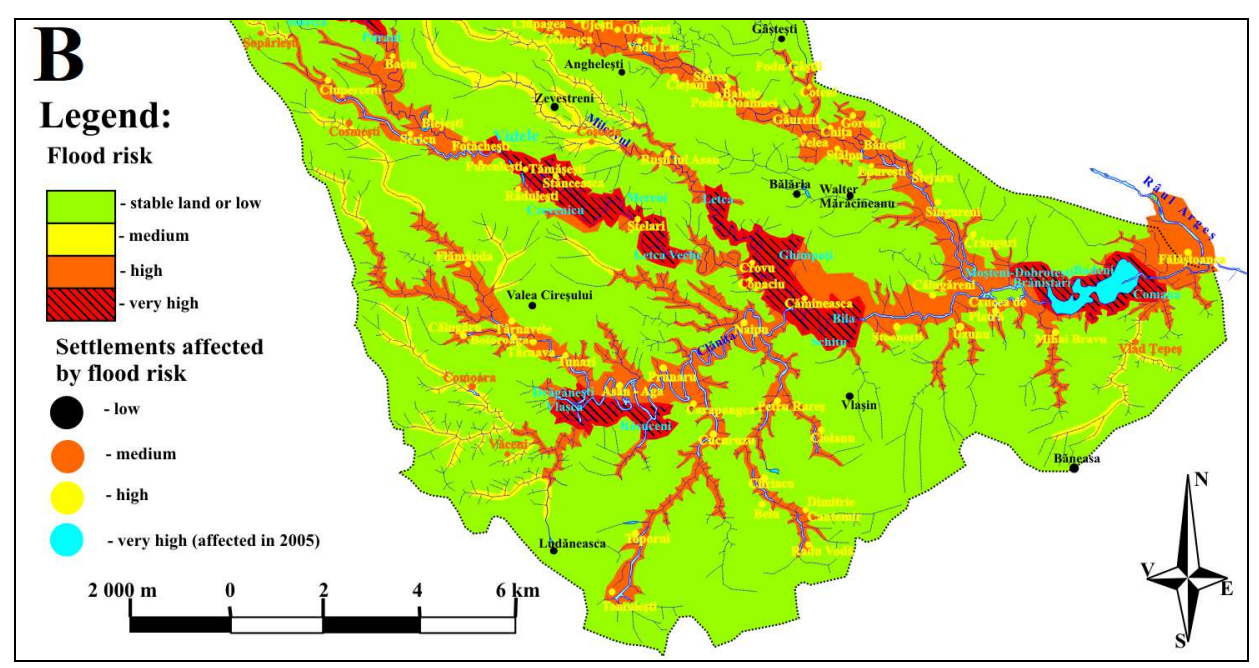

Fig. 1. Vulnerability map medium scale (B) in Romanian Plain (Grecu et al. 2012)

\section{Hazard - vulnerability - risk}

\subsection{Geomorphological hazard map and geomorphological process map legend}

An essential feature of the geomorphological hazards is the cohabitation with the pedological ones (which diminishes the quality of the soil) with a long-term effect on the risk elements, by degrading the land (Grecu 2009). As for the frequency of hazards, this is directly related to land degradation. The higher the frequency, although the magnitude decreases, the more surface area and intensity of land degradation increases and the recovery time for agrosilvic uses is longer (Grecu 2018a, 2018c). For the Romanian territory, the occurrence and dynamics of geomorphological hazards are influenced by the geological (structural, petrographic, seismic), climatic (with altitude values), hydrological and anthropic factors. Therefore, the most exposed to geomorphological hazards, especially landslides (Surdeanu 1999; Grecu at al. 2003; Gârbacea 2013) and erosion (Florea 2003), are the units of hills and plateaus (Figure 2). 


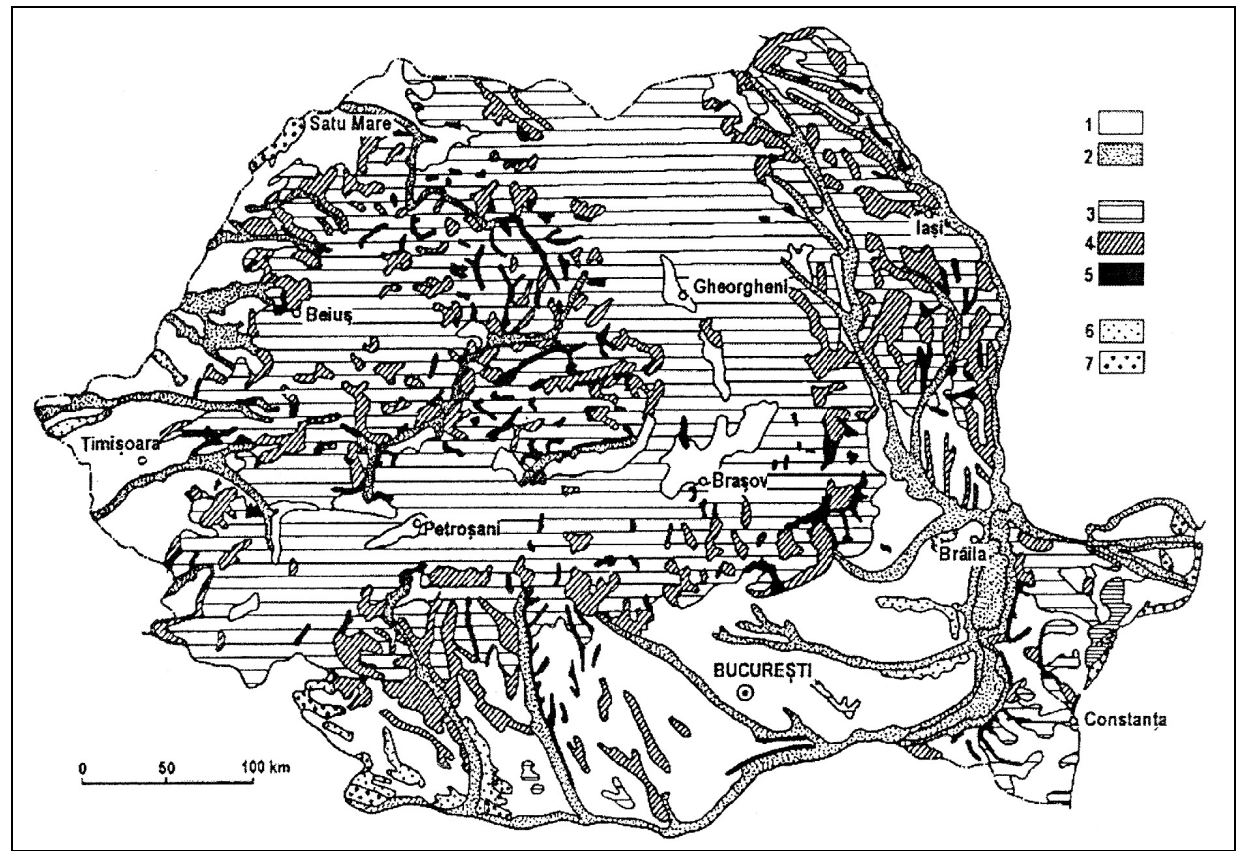

Fig. 2. General map of soil erosion in Romania. Erosion-free lands: 1 without flood risk; 2 flood and alluvial risk; Areas affected by water erosion: 3 low erosion but accelerated erosion risk, 4 moderate strong erosion with accelerated erosion risk, 5 very strong, excessive erosion; Terrains affected by wind erosion: 6 moderately strong erosion at risk with accelerated erosion; 7 very strong, excessive erosion (N. Florea et al. 1999 with modifications, in Grecu 2018a)

\subsection{The vulnerability map}

The map of vulnerability to hydrogeomorphological processes or to hydrogeomorphological hazards is a synthetic map that highlights both the current state of the dynamics of the relief, as well as the tendency of the changes in the analyzed systems, as well as the evolution of the human-environment relations. Being a synthetic map, it is based on analytical maps, elaborated on the basis of quantitative indices (Grecu 1994/1997). Therefore, most vulnerability and / or risk maps are based on in-depth studies carried out either in doctoral theses (see doctoral theses of the last 10 years) or in research projects. 
The basic requirement is the mapping of the main factors that influence the dynamics of the hazard, the establishment of the critical values of the dynamics (Grecu 1992, 2003, 2018b; Petrea 1998; Sandu M. and Bălteanu 2005; Goțiu D and Surdeanu V 2008), as well as their consequences. In case of floods, it is necessary to know the phenomenon from a hydrogeomorphological point of view and therefore the use of the hydrogeomorphological method (HGM) (Masson et al. 1996; Malavoi J.R. and Bravard J.P. 2010; Ballais Jean-Louis et al. 2014). The functional geomorphological units of the functional alluvial plain after the HGM are given for rivers from temperate regions (Cyrile Fleurant et al 2013; Badea et al. 1983), requiring the elaboration of a mapping methodology for the floods for rivers from cold temperate or warm arid climates.

The maps of natural risk to floods are prepared based on studies, according to Law no. 575/2001, which provides in art. 3 (1): „The geographical delimitation of the natural risk areas is based on specific studies and research elaborated by specialized institutions". Natural risk maps are part of the documentation for spatial planning according to H.G. no. 447/2003 for the approval of the methodological norms regarding the elaboration and the content of the natural risk maps for landslides and floods, in Annex no. 2, chap. I, art. 3.

In Romania, flood maps and vulnerability to floods are based primarily on climate-hydrological data, less on hydrogeomorphological data. This way, the applied characteristic is diminished, the maps do not highlight the form of relief and the use of it. Most flood maps are developed after the occurrence of this phenomenon (Zăvoianu I. and Podani M. 1977; Arnaud-Fassetta et al. 2005).

Regarding the water erosion on the slopes, it was based on the application of the USLE formula (Figure 3) or other models and formulas that can be quantified especially in doctoral works. However, the first maps were based on the data obtained in experimental stations or by applying indirect methods, especially by using the data recorded at the stations and the meteorological and hydrological stations (Grecu et al. 2008, 2012, 2013a, 2013b; Ionita 2000, 2006, 2007; Irimuş 2006; Petrea 1998; Surdeanu 1999; Rădoane et al. 1999; Mărgărint et al. 2013). 


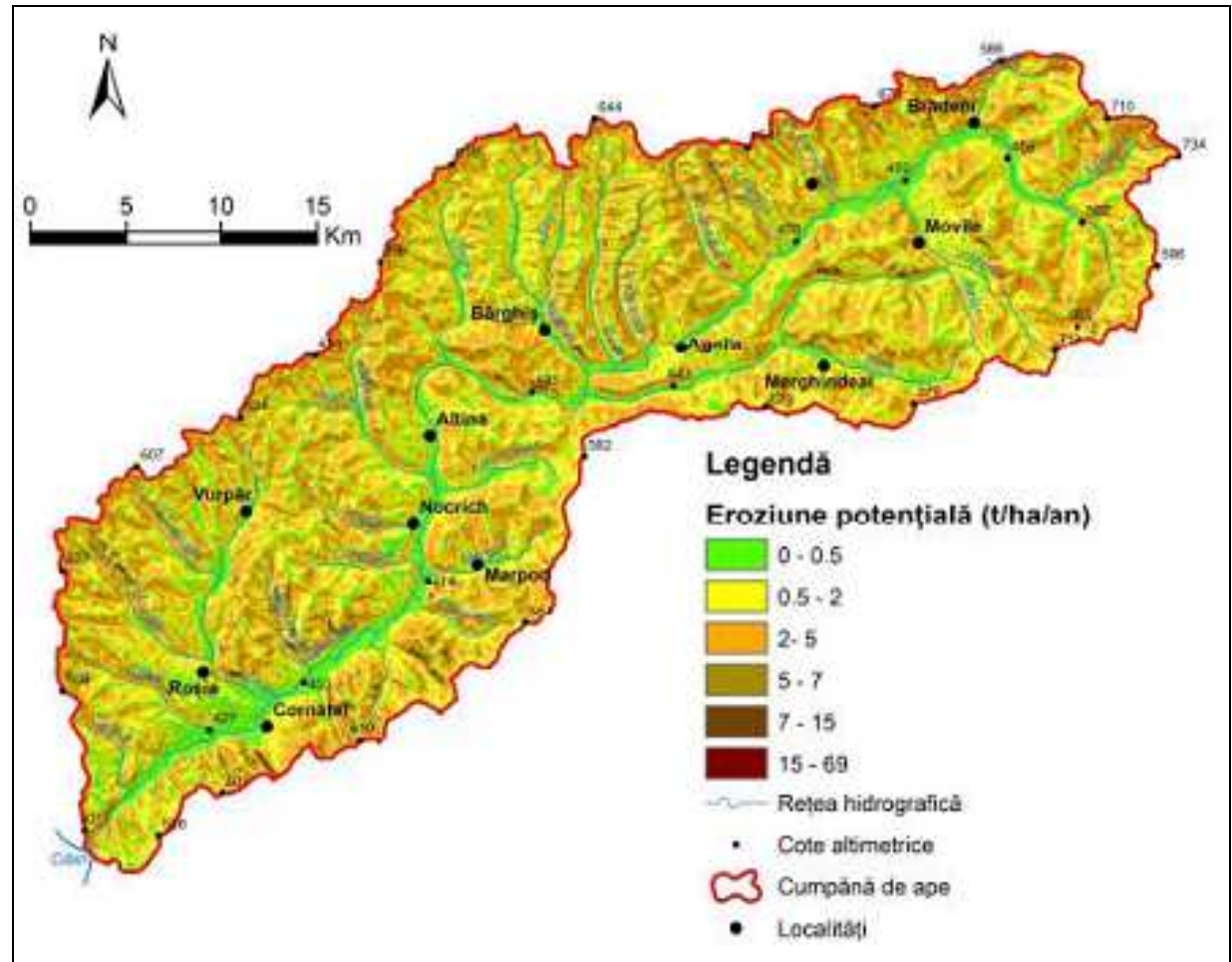

Fig. 3. Map of the potential erosion of the Hartibaciu river basin elaborated on the basis of the USLE formula (Grecu 2013)

\subsection{Map of the geomorphological risk of the territory of Romania - small and medium scale}

\subsubsection{Highlights of the evolution of geographical thinking in Romania}

The representation of geomorphological risk on maps is not a recent concern, although the most important achievements belong to the last two decades. The mapping of the geomorphological risk was initially linked to the extreme phenomena with catastrophic effects that produced radical changes in the landscape, losses of human lives and economic damages, such as: volcanic eruptions, earthquakes, large-scale landslides, typhoons, catastrophic floods and others (Rusu 2008; Teodor 2013, 2014, 2015). 
Awareness of these phenomena, both from the perspective of causes and especially of the effects, had as purpose the establishment of specialized groups at governmental level and within international organizations and programs.

The importance of risk maps was highlighted by Coteț in a study published in the journal Terra (1978).

The first risk maps developed in Romania were made in doctoral theses (Schreiber 1980, 1994; Teodor 2017), or in regions where the authors had detailed research (Balteanu et al. 1989; Grecu 1997, 2002a, 2002b; Grecu et al. 2012; Balteanu et al. 2012; Grecu et al. 2014, 2017; Josan et al. 2004; Voiculescu 2002; Armaş 2006; Sandulache 2010; Driga et al. 2007 etc.). The quantitative method, of evaluating the morphodynamic potential in areas reduced as surface, by numbers or symbols (the method of cartograms with reduced surfaces) (Grecu 1992, 2002; Jurchescu and Grecu, 2015), allowed the map to be elaborated based on the causal factors. The method was subsequently developed through computer programs, each factor / criterion being analyzed and represented by a unique cartography, from which the overall risk map results, by means of the multicriteria method. The methodological norms regarding the elaboration and the content of the risk maps for landslides and floods (Section V - Natural risk areas. Official Monitor 305, Government of Romania HG 447/2003) synthesized the research in the field and imposed a relatively unitary methodology, but which can be neglected depending on the geographic features of the analyzed territory and the author's options.

In Romania, the concerns in the field, initially isolated, were mainly focused on small relief units and having varied methodologies, the most used being the multicriteria method, which is found in the use of the GIS technique, especially in works published in the last two decades. The need for these maps was pointed out by Coteț (1978). Gradually, the risk maps were elaborated especially in the units studied in detail as doctoral theses, without having applied a unitary methodology.

In the last two decades, the elaboration of the risk maps has been the object of some works focused on field research but also on the synchronization with the world research in the field. The risk maps focused almost exclusively on hill and plateau areas, with a large agricultural and habitat potential (Buzău Subcarpathians, Transylvanian 
Plateau, Getic Plateau and Subcarpathians, Moldova Plateau), as well as, in part, mountain units. Bogdan and Niculescu (1999) realizes a regionalization of the climatic risk phenomena at country level.

A relatively new trend is the diversification of risk maps, their grouping on several thematic categories, types of scales, according to purpose etc., criteria underlying the classification of the maps.

Due to the complexity of the phenomena it supports in elaboration and which it reproduces by intensity, the map of the exposure to the geomorphological risk is one of the most pragmatic maps, but also more important for the dynamics of the phenomena. Apparently a simple map through the qualitative gradations of the phenomenon, it is revealed as a map that can be compared with the geological or pedological ones, for example, when they are rendered in colors.

Thematically, risk research in Romania was oriented to the following directions, which also include mapping aspects (without being exhaustive):

- theoretical problems regarding the terminology, the methodology of the research of the extreme phenomena;

- environmental risk assessment and analysis, regional studies including mapping of extreme processes;

- analysis of different risk phenomena, vulnerability;

- hazard and risk mapping and mapping; evaluation techniques;

- applicative studies aimed at the degradation of geosites.

\subsubsection{The legend}

Risk mapping is based on hazard maps/geomorphological processes, vulnerability maps (Figures 4,5 ). Therefore, the risk classes are the same as the vulnerability classes and they render the quality, intensity of the phenomenon based on quantitative analysis. In Romania, the geomorphological studies since at the end of the last century approached the risk phenomena within chapters on geomorphological processes and/or chapters with an applicative character (Schreiber 1994; Niacșu et al 2008). Thus, the risk assessment 
classes are established according to the main criterion / criteria underlying the analysis of the single vulnerability, in: low risks, medium risks, high risks. In the context of multicriteria analysis, the evaluation classes are diversified into: very low (no risk), low, medium, high and very high (Grecu 2002a, 2002b). In the case of environmental risk, the decomposition is done on environmental components considered in the multicriteria analysis. In the case of the general risk, the impact effects of the risks on the socio-economic activities are taken into consideration. Most of the risk studies for landslides and floods in the last decade take into consideration the criteria provided by the 2003 law, having a unitary character from this point of view and from the point of view of the legend.

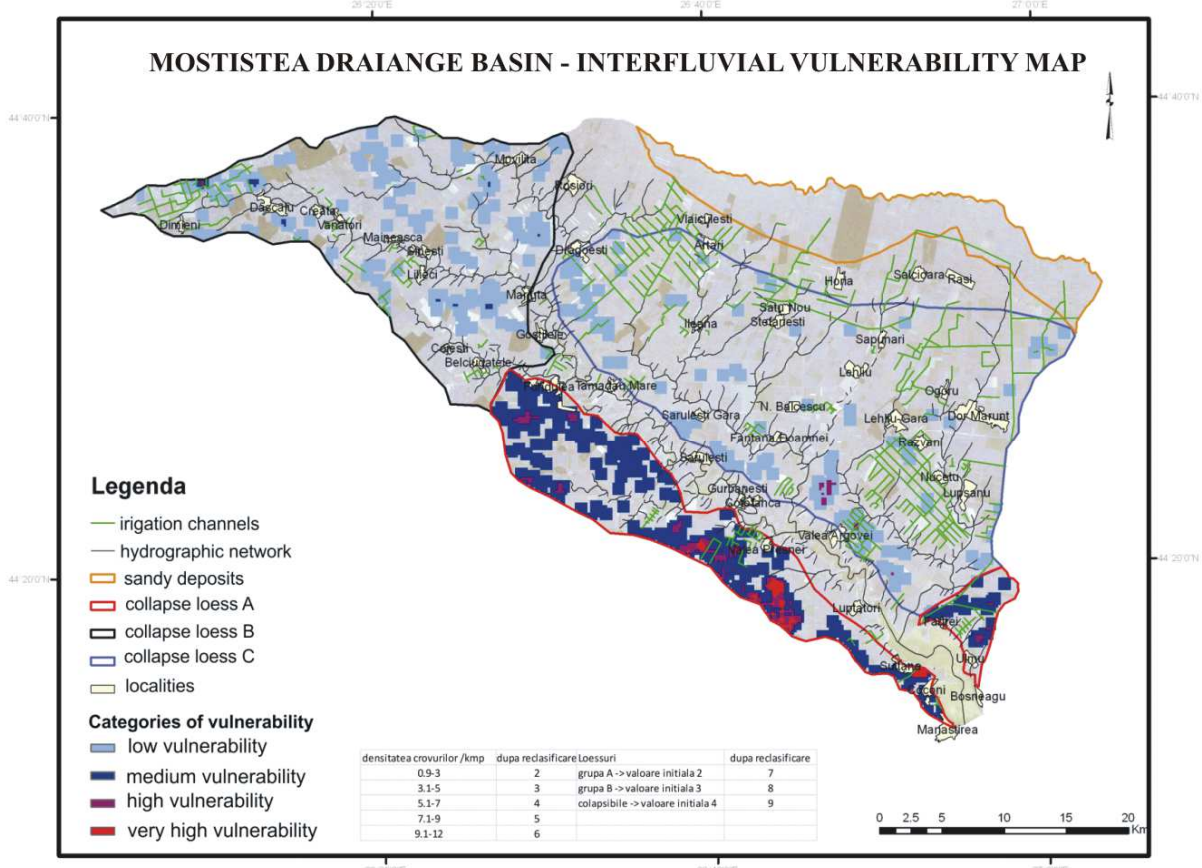

Fig. 4. Map of vulnerability to geomorphological processes in the plains (Grecu et al. 2013) 


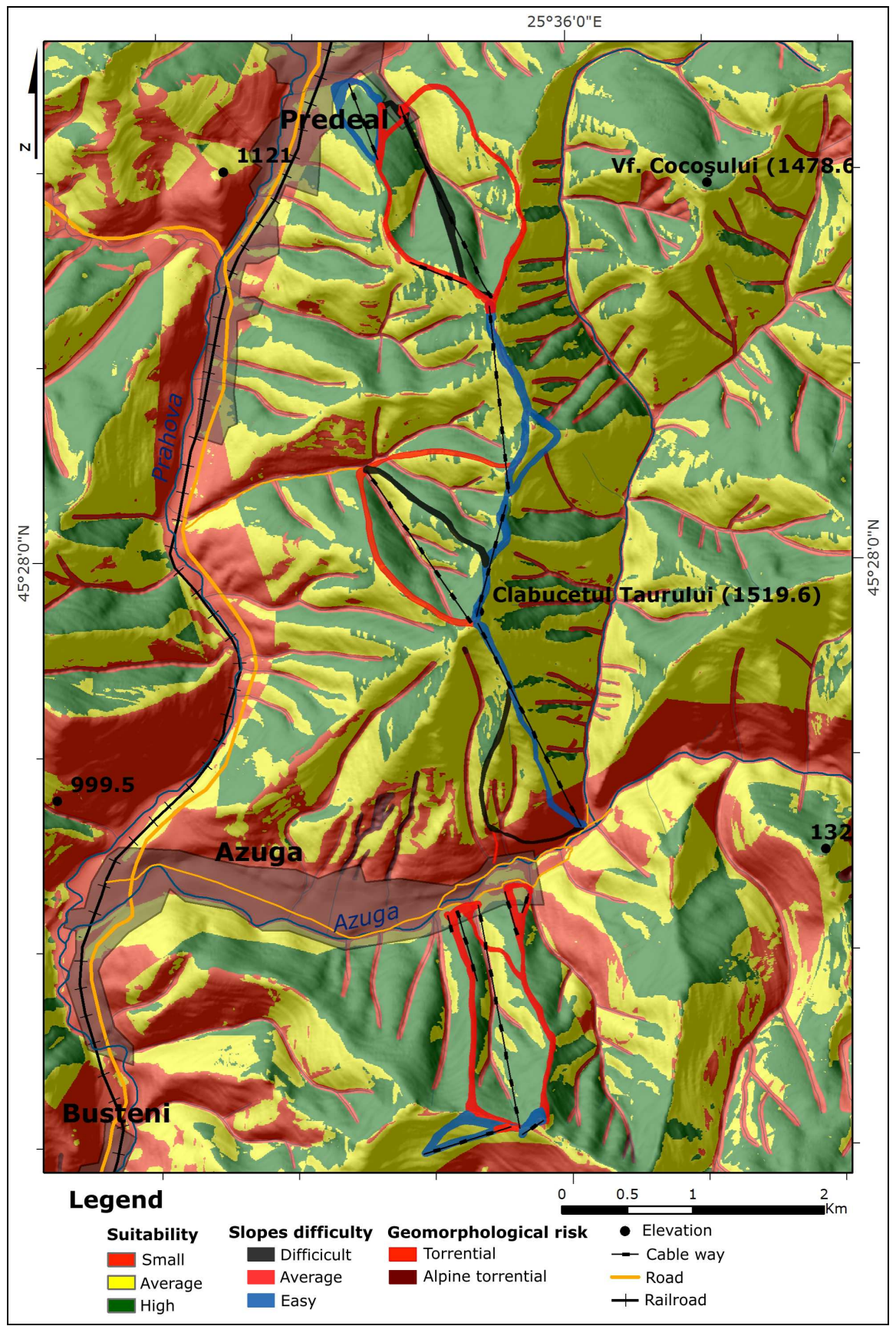

Fig. 5. Vulnerability map for the mountain region (Baiului Mountains) (Teodor 2015) 
The map of the geomorphological risk on a small scale (Figure 1A, Figure 2), due to the generalization guard on large spaces, imposes a generalized legend according to the factorial geographical features, as follows: low risk, medium risk, high risk. In areas with low or low general risk, high risk areas may occur at certain hazards. This is the case of the Romanian plain, where high or very high-risk areas occur during earthquakes or floods, on a general low risk area (Figure 1).

\section{Conclusions}

The forms resulting from the dynamics of the relief, including their quantitative and qualitative aspects, have a special practical importance, imposing the area mapping of the affected territory.

That is why mapping and mapping risk/vulnerability involves mapping the forms and processes that could have a negative effect on the population and the environment.

In Romania the mapping of the geomorphological risk was / is related more to the finding of auxiliary methods dependent on the scale of representation.

Concrete aspects of mapping, of the typology of processes / hazards are a constant concern in the specialized literature.

\section{REFERENCES}

Armaş, I. (2006), Risc şi vulnerabilitate.Metode de evaluare aplicate în geomorfologie. Editura Universității din Bucureşti.

Arnaud-Fassetta, G., E. Cossart, M. Fort, 2005, Hydro-geomorphic hazards an impact of man-made structures during the catastophic flood of June 2000 in the Upper Guil catchment (Queyras, Southern French Alps). Geomorphology 66:41-67.

Ballais, Jean-Louis, Sylvain Chave, Nadia Dupont, Éric Masson et Marie-Josée Penven, 2014, La méthode hydrogéomorphologique de détermination des zones inondables, Physio-Géo [En ligne], Volume 5 | 2011, mis en ligne le 03 janvier 2011, Consulté le 24 juin 2014. URL: http://physio-geo.revues.org/3307; DOI: 10.4000/physio-geo.3307.

Băican, Vasile (1996), Geografia Moldovei reflectată în documentele cartografice din secolul al XVIII, editura Academiei Române, București, 164 p. 
Bălteanu, D., Dinu, M., Cioacă, A. (1989), Hartile de risc geomorphologic (Exemplificari din Subcarpatii si Podisul Getic, Studii şi cercetari geol., geofiz., geografie, geografie, XXXI, 9-13.

Bălteanu, D, Jurchescu, M, Surdeanu, V. et al (2012), Recent landform evolution in the Romanian Carpathians and Pericarpathian regions. In: Loczy, D., Stankoviansky, M., Kotarba, A. (eds), Recent landform evolution. Springer, The Carpatho-Balcan-Dinaric Region, pp. 249-286.

Cyril, Fl., Douvient, J., Delahaye, D., 2013, Introduction du numéro thématique: „Hydro-géomorphologie Quantitative”. Geomorphologie: relief, processus, environnement, 1:3-6.

Bogdan, O., Niculescu, E., 1999, Riscurile climatice în România, Institutul de Geografie, București.

Dramis, F., Bisci, C. (1998), Cartografia geomorfologica, pitagora Editrice, Bologna.

Coteț, P. (1978), O nouă categorie de hărți, hărțile de risc şi importanâța lor geografică, Terra $X(X X X), 3$.

Driga, B. (ed) (2007), Riscurile naturale din județul Satu Mare. Edit Arvin Press, Bucureşti.

Florea, N. (2003), Degradarea, protecția și ameliorarea solurilor și terenurilor. Societatea Națională Română de Știința Solului, București.

Gârbacea, V. (2013), Relieful de glimee. Presa Universitară Clujeană, Cluj-Napoca.

Goțiu, D., Surdeanu, V. (2008), Hazardele naturale și riscurile asociate din Țara Hațegului. Presa Universitară Clujeană, Cluj-Napoca.Romane, București.

Grecu, F. (1997), Etapele întocmirii hărții expunerii la risc a terenurilor din bazine hidrografice de deal, Memoriile Secț Ştiințifice ale Academiei, Ser IV, XVII,1994, 307-323.

Grecu, F. (2002a), Mapping geomorphic hazards in Romania: small, medium and large scale representations of land instability. Géomorphologie, Relief, Processus, Environemant 2: 197-206.

Grecu, F. (2002b), Risk-prone lands in hilly regions: mapping stages. In: Allison R.J. (ed) Applied geomorphology. Wiley, Chichester, pp. 49-64.

Grecu, F. (2009, 2016), Hazarde și riscuri naturale, 4/5 th edn. Editura Universitară, București.

Grecu, Florina (2013), Degradarea terenurilor prin eroziune hidrica, Comunicări științifice, XII, Collegium Mediense III, Mediaș, 207-211, ISSN 2247-7772, ISSN-L = 2247-7772.

Grecu, Florina (2018a), Geomorphologic Hazard in Romania.Typology and Areal distribution In Water Management and the Environnment. Case Studies, edMartina Zelenakova, Springer International Publ., https://doi.org10.1007/978-3319-79014-5_5, 85-99.

Grecu, Florina (2018b), Geomorfologie dinamică pluvio-fluvială. Teorie şi aplicații, Editura Universitară, 480 p., 264 figuri, 70 tabele, 503 titluri bibliografice.

Grecu, Florina, editor (2018c), Lucrări şi rapoarte de cercetare, Centrul de cercetare "Degradarea terenurilor şi dinamica geomorfologică", vol. IV, Natural and antropic risk, Edit. Universităţii din Bucureşti, 126 p.

Grecu, Florina, Palmentola, G. (2003), Geomorfologie dinamică, Editura Tehnică, Bucureşti.

Grecu, F, Ioana-Toroimac, G., Dobre, R. (2008) Précipitations et risques naturels durant la dernière décennie dans le département de Prahova (Roumanie). In: Actes du XXI ${ }^{\mathrm{e}}$ Colloque de l'Association Internationale de Climatologie, Montpellier, 9-13 Sept. 2008. 
Grecu, F., Zaharia, L., Ghiță, C., Comănescu, L., Cîrciumaru, E., Albu-Dinu, M. (2012), Sisteme hidrogeomorfologice din Câmpia Română. Hazard - vulnerabilitate risc. Editura Universității din București, București.

Grecu, Florina, Ghiță, Cristina, Budileanu, Marius (2013a), Vulnerability map to hydrogeomorphological processes (Romanian Plain), Revista de geomorfologie, vol. 15.

Grecu, F., Zaharia, L., Ghiță, C. (2013b), Hydrogeomorphological vulnerability in the Romanian Plain. Z Geomorph 57(3): 3-28. https://doi.org/10.1127/0372-8854/2013/S-00141.

Grecu, F., Ioana-Toroimac, G., Constantin (Oprea), D.M. (2014), Le critère pluviométrique Angot dans la détermination de la susceptibilité du terrain aux aléas géomorphologiques en Roumanie. In: Actes du XXVII Colloque de l'AIC, Dijon, 2-5 July 2014.

Grecu, F., Zaharia, L., Ioana-Toroimac, G. et al (2017), Floods and flash-floods related to river channel dynamics. In: Rădoane, M., Vespremeanu-Stroe, A. (eds), Landform dynamics and evolution in Romania. Springer, Cham, pp. 821-844.

Guvernul României (2003) HG 447/2003 - Norme metodologice privind modul de elaborare şi conținutul hărților de risc la alunecări de teren. Section V - Zone de risc natural. Official Monitor 305.

Ioniță, I. (2000), Geomorfologie aplicată. Editura Universității A.I. Cuza, Iași.

Ioniță, I. (2006), Gully development in the Moldavian Plateau of Romania, Catena 68: 133-140.

Irimuș, A. (2006), Hazarde și riscuri asociate proceselor geomorfologice în aria cutelor diapire din Depresiunea Transilvaniei. Editura Cărții de Știință, Cluj-Napoca.

Josan, N., Sabău, N.C. (2004), Hazarde și riscuri naturale și antropice în bazinul Barcăului. Editura Universitătii din Oradea, Oradea.

Jurchescu, M., Grecu, F. (2015), Modelling the occurrence of gullies at two spatial scales in the Olteț Drainage Basin (Romania). Nat Hazards 79: 1-37. https://doi.org /10.1007/s11069-015-1981-6.

Malavoi, J.-R., Bravard, J.-P., 2010, Elements d'hydromorphologie fluviale, Onema: http://www.onema.fr/hydromorphologie-fluviale.

Masson, M., Garry, G., Ballais, J.-L., 1996, Cartographie des zones inondables. Approche Hydrogéomorphologique. Edit.Villes et territoires, Paris.

Mărgărint, M.C., Grozavu, A., Patriche, C.V. (2013), Assessing the spatial variability of coefficients of landslide predictors in different regions of Romania using logistic regression. Nat Hazards Earth Syst Sci 13:3339-3355. https://doi.org/10.5194/ nhess-13-3339-2013.

Osaci-Costache, Gabriela (2008), Cartografie, Editura Universitară, București.

Petrea, Dan (1998), Pragurile de substanță, energie şi informație în sistemele geomorfologice, Edit Universității din Oradea, Oradea.

Rădoane, M, Rădoane, N, Ichim, I. et al (1999), Ravenele. Forme, procese, evoluție. Editura Presa Universitară Clujeană, Cluj-Napoca.

Rusu, C. (ed) (2008), Impactul riscurilor hidro-climatice şi pedo-geomorfologice asupra mediului în bazinul Bârladului. Editura Performantica, Iaşi.

Sandu, M., Bălteanu, D. (eds) (2005), Hazardele naturale din Carpaţii şi Subcarpaţii dintre şi Teleajen. Studiu geografic, Editura Ars Docendi, Bucureşti.

Săndulache, C. (201...), Hazarde și riscuri naturale în Munții Parâng.Ed Universitară, București. 
Schreiber, W.E. (1980), Harta riscului interventiilor antropice in peisajul geografic al Muntilor Harghita, Studii si cercetari de geologie, geofizica, geografie, Geografie, XXVII, 1.

Schreiber, W.E. (1994), Munții Harghita. Studiu geomorfologic, Edit. Academiei, Bucuresti, $136 \mathrm{p}$.

Sficlea, V., Popovici, I. (1983), In: Badea, L., Băcăoanu, V., Posea, Gr., coord., Geografia României, vol. I., Geografia fizică. Editura Academiei Române, București, pp. 64-187.

Surdeanu, V. (1999), Geografia terenurilor degradate. Editura Presa Universitară Clujeană.

Teodor, Mădălina (2013), Geomorphological processes susceptibility assessment using GIS analysis in Ilwis software. Case study: Ialomița Upper Valley (Romania), Revista de Geomorfologie, Nr. 15.

Teodor, Mădălina, Robert Dobre, Florina Grecu, Ionuț Săvulescu (2014), Vulnerability of the geomorphological processes of new proposed ski areas. Case study: PredealAzuga (Romania) resorts in The geomorphology of natural hazards: mapping, analysis and prevention. Abstract book, 17 th Joint Geomorphological Meeting, Liege 129-130.

Teodor, Mădălina, Robert Dobre (2015), Relief suitability for developing a macro ski area between Predeal and Azuga resorts, Revista de Geomorfologie, Nr. 17, 2015.

Teodor, Mădălina (2017), Aplicații GIS pentru proiectarea, dezvoltarea și managementul domeniilor schiabile din România, Editura Universitară, ISMB 978-606-28-0620-0, DOI: $10.5682 / 9786062806200$.

Voiculescu, M. (2002), Fenomene geografice de risc în Masivul Făgăraș. Editura Brumar, Timișoara.

Zăvoianu, I., Podani, M. (1977), Les inondation catastrophiques. Revue roumaine de geologie, geophisyque, geographie, Serie Geographie, XX. 